\title{
Development of bioenergy plantation in Indonesia: yield regulation and above-ground carbon storage in Gliricidia (Gliricidia sepium) plantation
}

\author{
Budi Mulyana*, Djoko Soeprijadi, Ris Hadi Purwanto \\ Department of Forest Management, Faculty of Forestry, Universitas Gadjah Mada, Yogyakarta, \\ Indonesia
}

\begin{abstract}
The development of gliricidia plantation (Gliricidia sepium) in Indonesia can be considered as a climate change mitigation action to reduce greenhouse gases emission. This paper investigates the yield regulation and potential above-ground carbon storage of gliricidia at Perhutani Forest Management Unit Semarang. The biomass production of gliricidia at various age $(1,2,3,4,5$ years) can be utilized to determine the biological cycle and estimating the potential above-ground carbon storage. The result showed that gliricidia could be harvested after 2-years to produce optimum biomass. Above-ground carbon storage in gliricidia plantation distributed in the tree $(94.73 \%)$, litter $(2.98 \%)$, and understorey plants $(2.29 \%)$. Total aboveground carbon storage in gliricidia plantation at age 1-5 years are $6.285,45$ $\mathrm{Mg} \mathrm{C}, 8.052,58 \mathrm{Mg} \mathrm{C}, 9.161,93 \mathrm{Mg} \mathrm{C}, 14.238,63 \mathrm{Mg} \mathrm{C}$, and 25.474,79 Mg $\mathrm{C}$, respectively.
\end{abstract}

Keyword. biomass, coppice system, climate change, mitigation

\section{Introduction}

Indonesia has been taking action on climate change mitigation. For instance, Indonesia has ratified the Paris Agreement in the Law No. 16 of 2016 and then submitted of National Determined Contribution (NDC) documents to the United Nations Framework Convention on Climate Change (UNFCC). The government of Indonesia has set the target to reduce emission by $29 \%$ (unconditional target) and up to $41 \%$ (conditional target) by 2030 . Furthermore, the forestry sector is projected to reduce greenhouse gases (GHG) emissions by $17,2 \%$ on an unconditional mitigation scenario.

The development of gliricidia plantations (Gliricidia sepium) in Java island is one of the strategies in mitigating climate change. Indonesia Forestry Enterprise (Perhutani) Forest

* Corresponding author: budimulyana@ugm.ac.id 
Management Unit (FMU) Semarang started to develop gliricidia plantation in 2012. Gliricidia plantations for bioenergy can produce biomass and storing the carbon [1,2]. On the other hand, activities on forest plantation management such as thinning and clear-cutting of the tree will affect the carbon storage decreasing [3].

The multipurpose forest management paradigm receives serious attention to be developed in sustainable forest management to tackle climate change issues. Multipurpose is the management of all resources so that they can be utilized in a combination that meets public needs, is used wisely, and is managed in a harmonious [4]. For instance, multipurpose forest management includes integration between wood production and carbon storage in teak plantations [5], a combination of wood supply, carbon storage and biodiversity [6,7], and production firewood and marginal land rehabilitation $[8,9]$.

The research aims were elaborating optimum biological cycle and potential above-ground carbon storage of gliricidia. The optimum biological cycle is vital in planning the yield regulation on gliricidia plantation as the bioenergy source. Whereas, above-ground carbon storage can be integrated on bioenergy forest management planning. Furthermore, the research is important to develop multipurpose forest management on bioenergy plantation in Indonesia, especially for gliricidia species.

\section{Research Methodology}

The research was conducted in the Perhutani FMU Semarang area. Field measurements were carried out in 2018 and 2019. The tools used in this study were compasses, GPS, digital scales, meter tape. Gliricidia plants, which were used as research material, planted in 2013, 2014, 2015, 2016, and 2017.

The primary data was obtained through field measurement that carried out in 2018 and 2019 to be the initial data for estimating biomass, determining biological cycles, and estimation carbon storage at the above-ground level. Temporary plot samples (TPS) of 0.01 ha were made on aged gliricidia plants that were distributed at each age. The area of TPS 0.01 refers to the Indonesian National Standard No. 7724 concerning the measurement and calculation of carbon stocks - field measurements for estimating forest carbon stocks [10]. The number of plots for each plant age amounted to 16 TPS, so the total TPS in this study amounted to 90 plots. Data collected in the forest inventory activities are fresh-cut weight $(\mathrm{kg})$, stem diameter $(\mathrm{cm})$, tree height $(\mathrm{m})$, age (years), plant density (trees/ha).

\subsection{Biomass measurement}

Estimation of gliricidia plant biomass referred to the allometric equation that was developed by Mulyana et al. [2]. The fresh-cut weight was predicted by stem diameter, which expressed in the equation as follows.

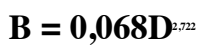

Where

B : Biomass

D : Stem diameter at height $30 \mathrm{~cm}$

Where

$$
\mathrm{Bp}_{\text {total }}=\frac{\sum_{i=1}^{n} B p_{i}}{L_{p l o t}}
$$


B : Biomass

D : Diameter at height $30 \mathrm{~cm}$

The biomass estimation results from each TPS are then used in the estimation of total biomass and the biological cycle of the gliricidia stand. Determination of biological cycles based on the intersection between current annual increment value (CAI) and the mean annual increment (MAI) [11-14].

\subsection{Carbon storage measurement}

The measurement of above-ground carbon storage includes the analysis of the fresh-cut weight and dry weight of the trees, litter, and understorey, then followed by testing in the laboratory for percentage carbon content [10]. Drying of samples was carried out at Laboratory in the Department of Forest Product Technology Universitas Gadjah Mada, while the testing of the percentage of carbon content from samples of gliricidia trees, litter, and understorey plants was carried out at the Soil Sciences Laboratory of the Faculty of Agriculture, Universitas Gadjah Mada.

Table 1. Percentage of carbon content at gliricidia plantation

\begin{tabular}{|l|l|c|c|}
\hline No & Carbon sources & Percentage of carbon content (\%) & Remarks \\
\hline 1 & Gliricidia tree & 57,40 & $(2)$ \\
& a. Stem & 56,30 & \\
& b. Branches & 52,90 & \\
& c. Leaves & 52,58 & Laboratory test \\
\hline 2 & Litter & 48,33 & Laboratory test \\
\hline 3 & Understorey plants & \\
\hline
\end{tabular}

Measurement of carbon storage in gliricidia trees refers to the allometric equation of gliricidia that was developed by Mulyana et al. [2], as follows

$\mathrm{B}=\mathbf{0 , 0 1 9 D ^ { 2 , 1 9 }}$

Where

B : Carbon storage in gliricidia $(\mathrm{Kg})$

D : Diameter at height $30 \mathrm{~cm}(\mathrm{~cm})$

In the TPS, the area of 0.01 ha consists of many gliricidia trees so that the total carbon in the gliricidia tree is the sum of the carbon storage within the plot. Hence, the equation to calculate the total carbon storage of gliricidia in each plot was as follows:

$$
\mathrm{Cp}_{\text {total }}=\frac{\sum_{i=1}^{n} C p_{i}}{L_{\text {plot }}}
$$

Where

$\mathrm{C}_{\text {puat }}$ : Total carbon storage $(\mathrm{Mg} \mathrm{C} / \mathrm{ha})$

$\mathrm{C}_{\mathrm{pi}} \quad:$ Carbon storage at gliricidia tree number-i (Mg C)

L : Temporary plot sample area (ha)

Measurement of carbon storage in litter and understorey plants refers to SNI No. 7724 of 2011 concerning the measurement and calculation of carbon stocks - field measurements for the estimation of forest carbon stocks [10]. The total carbon storage on the above-ground level can be calculated using the following equation 


$$
C_{\text {total }}=C_{\text {tree }}+C_{\text {iture }}+C_{\text {understory phuns }}
$$

Where

$\begin{array}{ll}\mathrm{C}_{\text {total }} & : \text { Total above-ground carbon storage }(\mathrm{Mg} \mathrm{C} / \mathrm{ha}) \\ \mathrm{C}_{\text {tree }} & : \text { Carbon storage in gliricidia tree }(\mathrm{Mg} \mathrm{C} / \mathrm{ha}) \\ \mathrm{C}_{\text {litter }} & : \text { Carbon storage in litter }(\mathrm{Mg} \mathrm{C} / \mathrm{ha}) \\ \mathrm{C}_{\text {understorey plants }} & : \text { Carbon storage in understorey plants }(\mathrm{Mg} \mathrm{C} / \mathrm{ha})\end{array}$

\section{Result and Discussion}

\subsection{Biomass estimation and yield regulation of gliricidia plantation}

The gliricidia plantation forest in the Perhutani FMU Semarang established in collaboration with Perhutani and the Korean Green Promotion Agency (KGPA) in 2012. The area of the gliricidia plantations established from 2013 to 2017 reached nearly 2,000 ha. Tree spacing of gliricidia plant stands at each planting age varied (Table 2.).

Table 2. Characteristic of gliricidia stand at KPH Semarang

\begin{tabular}{|c|c|c|c|c|}
\hline \multirow{2}{*}{$\begin{array}{c}\text { Age } \\
\text { (year) }\end{array}$} & \multirow{2}{*}{ Spacing } & \multirow{2}{*}{$\begin{array}{c}\text { Number of } \\
\text { samples (TPS) }\end{array}$} & \multicolumn{2}{|c|}{ Average of biomass } \\
\cline { 4 - 5 } & & 16 & Tree (kg/tree) & Plot (kg/plot) \\
\hline 1 & $2 \times 1$ & 16 & 13,93 & 139,93 \\
\hline 2 & $2 \times 1$ & 16 & 25,96 & 206,08 \\
\hline 3 & $2 \times 1$ & 16 & 60,20 & 142,66 \\
\hline 4 & $3 \times 1$ & 16 & 32,17 & 714,71 \\
\hline 5 & $1 \times 1$ & &
\end{tabular}

Gliricidia plants in the measurement in the temporary plot sampling (TPS) showed that the older the plants, the higher the biomass produced per tree. However, biomass per tree showed an interesting phenomenon in the average biomass of gliricidia plants in the age 4year $(60.20 \mathrm{~kg} /$ tree $)$ higher than the gliricidia plants at the age of 5 -year $(32.17 \mathrm{~kg} /$ tree $)$. Based on table 2 , the productivity of gliricidia plants is most likely influenced by the difference in spacing, so that the density of the plants will be different. It was consistent with the Willebrand et al. 's research in plantations with coppice systems that have denser plant densities that will have lower biomass production compared to those with lower plant densities [15]. Gliricidia plants with the spacing of 2 x 1 applied in the 2015-2017 planting year showed that the older the plant, the productivity will increase

The production of gliricidia plant biomass at different planting years can be utilized in determining the biological cycle. The biological cycle is generally calculated to determine the maximum tree dimension (volume or biomass). The biological cycle determined by the intersection between the current annual increment (CAI) and the mean annual increment (MAI) $[11,13,16]$. The results showed that the biological cycle of gliricidia plants in FMU Semarang was 2 or 5 years (Figure 1) 


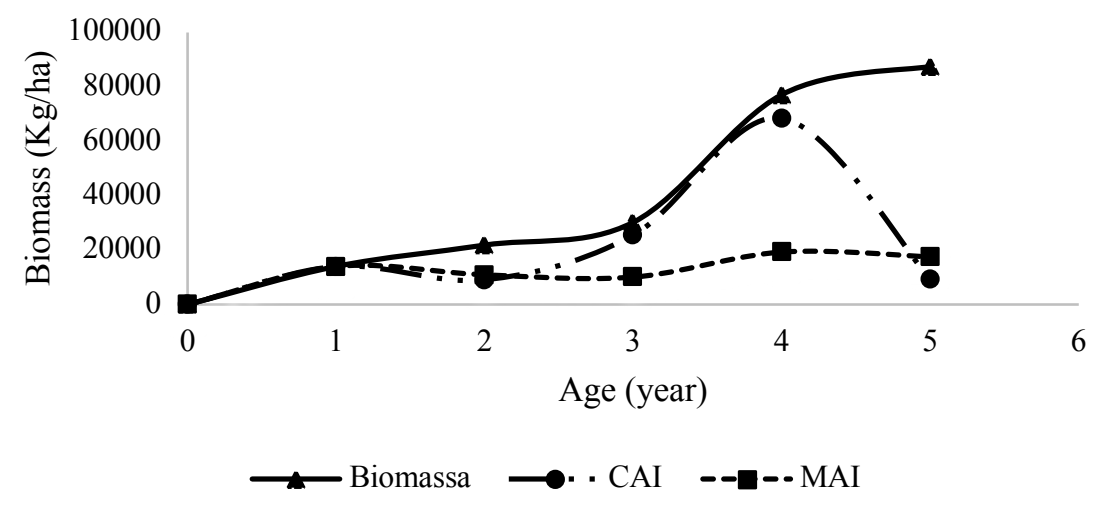

Figure 1. Biomass growth of gliricidia at KPH Semarang

Gliricidia plants were plants that were cultivated with a coppice system with the aim of a source of bioenergy raw materials. The intersection between CAI and MAI in gliricidia plants was at the point of 2-years and 5-years. This phenomenon also occurred in cajuput plantation that was cultivated by the leave-twigs coppice system at KPH Yogyakarta, where the intersection of CAI and MAI was at two points [17].

Gliricidia plants in KPH Semarang could be harvested if they were at least 2 years old. The results of this study were also in accordance with Eufrade et al. 's research, where plants grown for bioenergy purposes with a coppice system in several European countries, Australia and New Zealand, have short cycles ranging from 2-4 years [18]. However, a cycle that was too short for a tree plantation with a coppice system (1-2 years) in Sweden was not necessarily better than another short cycle (4-6 years) [15]. Weger et al. 's research in a tree plantation with a cube system in Czech showed that the productivity of biomass in the 6-year cycle was higher than the 3-year cycle [19]. Thus, further research on the best cycle for gliricidia plantations in KPH Semarang can be more focused by comparing 2 and 5-year cycles.

\subsection{Carbon storage}

The distribution of above-ground carbon storages in the plots was dominated by carbon storage in trees section (Figure 2). The average carbon storage in trees reached $94.73 \%$, followed by carbon storages in the litter (2.98\%) and understorey $(2.29 \%)$. Siarudin \& Indrajaya's research results in community forests planted with Gmelina species also showed that above-ground carbon storages were dominated by trees (96.7\%) [16]. This phenomenon was found in bamboo stands, where above-ground carbon storages of the stems made up 80$90 \%$ of the total above-ground carbon storages [20]. 


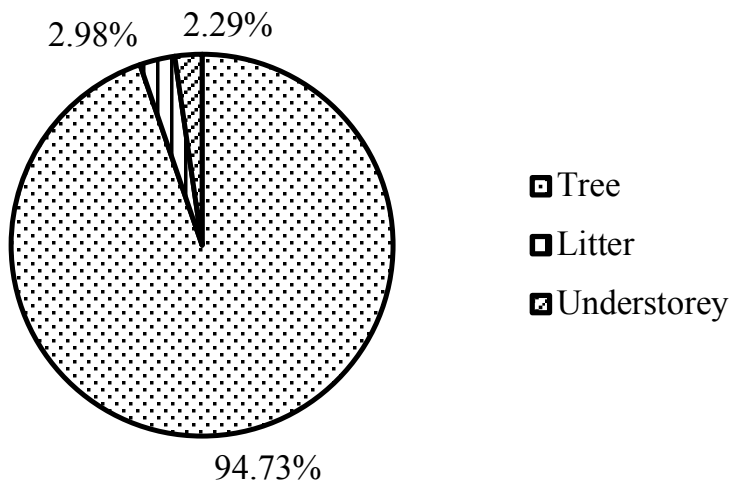

Figure 2. Distribution of above-ground carbon storage at Gliricidia plantation

Carbon storage in gliricidia plants varied in each age. The most significant storage was on the gliricidia plants, which was planted in 2013 (25,474.79 tons). Whereas, the smallest was in the gliricidia plants, which was planted in 2017 (6,285.45 tons) (Table 3). The variation in total carbon storages was affected by the whole areas and the age of the gliricidia plant. The gliricidia plant became more extensive, and the biomass becomes more abundant in the oldest stand [2]. The proportion of above-ground biomass in some forest types in the tropics showed a pattern that if diameter increases so the biomass will be higher [21].

Table 3. Above-ground carbon storage at gliricidia plantation

\begin{tabular}{|c|c|c|c|c|c|}
\hline \multirow{2}{*}{$\begin{array}{c}\text { Age } \\
\text { (year) }\end{array}$} & \multirow{2}{*}{$\begin{array}{c}\text { Area } \\
\text { (ha) }\end{array}$} & \multicolumn{2}{|c|}{ Above-ground carbon storage (Mg C/ha) } & Total above-ground \\
\cline { 3 - 5 } carbon storage (Mg C)
\end{tabular}

The average of above-ground carbon storage in gliricidia plantation was $31.91 \mathrm{Mg} \mathrm{C} / \mathrm{ha}$. The above-ground carbon storage in the short rotation coppice system for the poplar plantation at the temperate zone reached $3.89-6.48 \mathrm{Mg} \mathrm{C} /$ ha [22]. Hence, above-ground carbon storage in tropical is higher than the temperate zone.

Above-ground carbon storage levels in tree sections were distributed in the stem, branches, and leaves. In general, carbon storage of gliricidia plants stored in branches $(86.39 \%)$, stems (12.29\%), and leaves (1.31\%) [2]. The most extensive distribution of carbon storage was in the branches due to the gliricidia's plant characteristics as multi-stem species (Figure 3). In contrast to Yusuf et al. 's research in surian plants (Toona sinensis Roem.) which have single-stem, the largest deposits are on stems $(66.75 \%)$ then followed by branches $(27.55 \%)$, stalk $(2.84 \%)$, and leaves $(2.87 \%)$ [23]. The distribution of carbon biomass in teak (Tectona grandis), which has a single-stem, shows that carbon storage in the stem is more than $50 \%$ of the total carbon stock of the tree [24]. 


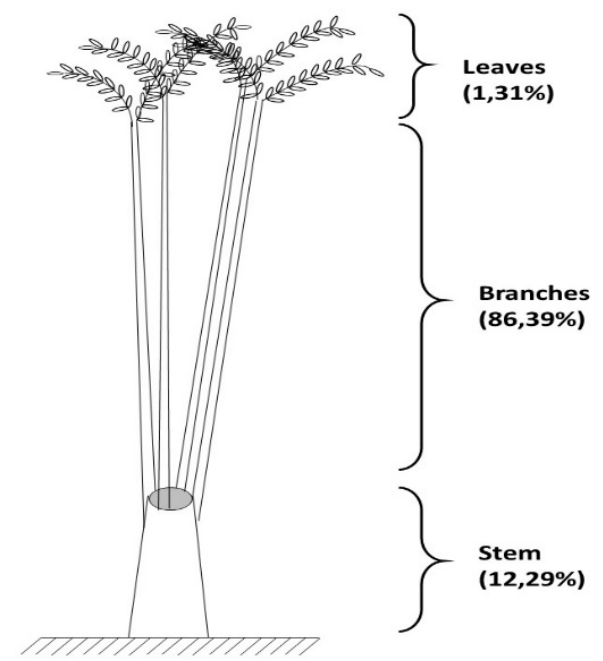

Figure 3. The distribution of biomass and carbon storage in Gliricidia tree

\section{Conclusion}

The research revealed that the optimum biological cycle for gliricidia was two years. The total above-ground carbon storage in the gliricidia stand increases with the increasing of plant ages. Whereas the carbon storages of litter and understorey were relative equally in each age of gliricidia stand. This conclusion only fits at Forest Management Unit (KPH) Semarang, and further research at other gliricidia plantation should be conducted at the different conditions of biophysical features.

\section{Acknowledgment}

We thank Faculty of Forestry Universitas Gadjah Mada that provide research grant No 120/KS/2018. We also appreciate Perhutani Divisi Regional Jawa Tengah, KPH Semarang, and people who have helped me during the research.

\section{References}

1. W. Zhou, L. Gao. The impact of carbon trade on the management of short-rotation forest plantations. Forest Policy and Economic 62:30-5 (2016)

2. B. Mulyana, D. Soeprijadi, R.H. Purwanto. Allometric Model Of Wood Biomass And Carbon For Gliricidia (Gliricidia Sepium (Jacq.) Kunth Ex Walp.) At Bioenergy Plantation In Indonesia. Forestry Ideas 26(1): 153-164 (2020)

3. J.H.M. Thornley, M.G.R. Cannell. Managing forests for wood yield and carbon storage : a theoretical study. Tree Physiology 20:477-84 (2000)

4. A. Tampubolon, R. Imanuddin, M.T. Zulkifli, B.L. Tobing, A. Suprihadhi, R. Wulandini, A.N. Hadi, A. Indrajaya, Ramdhani, M.S. Manurung, D. Sulastiyo, N. Idris, N. Cahyaningsih, E.B. Wiyono, A. Wahyu, D. Nurochman, H. Wiyoga, R. Pribadi. Toolkits Perencanaan Multiguna Hutan, Buku A: Pengantar Operasional dan Pengertian. Pusat Penelitian dan Pengembangan Hutan, Badan Penelitian, Pengembangan dan Inovasi Kementerian Lingkungan Hidup dan Kehutanan, Bogor (2018) 
5. T. Tiryana. Simulating Harvest Schedule for Timber Management and Multipurpose Management in Teak Plantations. Jurnal Manajemen Hutan Tropika 22(1):1-12 (2016)

6. T. Heinonen, T. Pukkala, L. Mehtätalo, A. Asikainen, J. Kangas, H. Peltola. Scenario analyses for the effects of harvesting intensity on development of forest resources, timber supply, carbon balance and biodiversity of Finnish forestry. Forest Policy Economic 80:80-98 (2017)

7. A. Nölte, H. Meilby, R. Yousefpour. Multi-purpose forest management in the tropics: Incorporating values of carbon, biodiversity and timber in managing Tectona grandis (teak) plantations in Costa Rica. Forest Ecology and Management 422:345-57 (2018)

8. R. Barro, M.J. Fern, P. Ciria. Production and composition of biomass from short rotation coppice in marginal land: A 9-year study. Biomass and Bioenergy 134:105478 (2020)

9. S.Y. Dillen, S.N.Djomo, N.A. Afas, S. Vanbeveren, R. Ceulemans. Biomass yield and energy balance of a short- rotation poplar coppice with multiple clones on degraded land during 16 years. Biomass and Bioenergy 56:157-165 (2013)

10. Badan Standarisasi Nasional. Pengukuran dan penghitungan cadangan karbon Pengukuran lapangan untuk penaksiran cadangan karbon hutan. Badan Standarisasi Nasional, Jakarta (2011).

11. Y. Indrajaya. Daur Optimal Hutan Tanaman Sengon Dalam Proyek Aforestasi: Review Hasil Penelitian Suharlan 1975. Jurnal Penelitian Kehutanan Wallacea 6(2):147-56 (2017)

12. Y. Indrajaya. Penentuan daur optimal hutan tanaman sengon (Paraserianthes falcataria L. Nielsen) dengan metode Faustmann. Jurnal Penelitian Agroforestry 1(1):31-40 (2013)

13. Y. Indrajaya, M. Siarudin. Pengaturan Hasil Agroforestry Jabon ( Neolamarckia cadamba Miq .) Dan Kapulaga ( Amomum compactum) Di Kecamatan Pakenjeng, Garut, Jawa Barat. Jurnal Penelitian Sosial dan Ekonomi Kehutanan 12(2):121-30 (2015)

14. Y. Indrajaya. Daur Optimal Hutan Rakyat Monokultur Dalam Konteks Perdagangan Karbon: Suatu Tinjauan Teoritis. Jurnal Penelitiaan Sosial dan Ekonomi Kehutanan 9(2):55-65 (2019)

15. E. Willebrand, S. Ledin, T. Verwijst. Willow Coppice Systems In Short Rotation Forestry: Effects of Plant Spacing, Rotation Length And Clonal Composition On Biomass Production. Biomass and Bioenergy 4(5):323-31 (1993)

16. M. Siarudin, Y. Indrajaya. Dinamika Cadangan Karbon Sistem Agroforestri Gmelina (Gmelina arborea Roxb.) Pada Hutan Rakyat Di Tasikmalaya Dan Banjar, Jawa Barat. Jurnal Wasian 4(1):37-46 (2017)

17. B. Mulyana, S.W.S. Siallagan, T. Yuwono, R.H. Purwanto. Daur Optimum Pemangkasan Daun Kayu Putih Di KPH Yogyakarta. Jurnal Penelitian Kehutanan Wallacea 8(1):71-9 (2019)

18. H.J. Eufrade, R.X. Melo, M.M.P. Sartori, S.P.S. Guerra, A.W. Ballarin. Sustainable use of Eucalypt biomass grown on short rotation coppice for bioenergy. Biomass and Bioenergy 90:15-21 (2016)

19. J. Weger, K. Vavrova, L. Kasparova, J. Bubenik, A. Komarek. The influence of rotation length on the biomass production and diversity of ground beetles (Carabidae) in poplar short rotation coppice. Biomass and Bioenergy 54:284-92 (2013)

20. M. Amoah, F. Assan, P.K. Dadzie. Aboveground biomass, carbon storage and fuel values of Bambusa vulgaris, Oxynanteria abbyssinica and Bambusa vulgaris var . vitata plantations in the Bobiri forest reserve of Ghana. Journal of Sustainable Forestry 39(2):113-36 (2020)

21. N.D. Preece, G.M. Crowley, M.J Lawes, P.V. Oosterzee. Comparing above-ground biomass among forest types in the Wet Tropics : Small stems and plantation types matter 
in carbon accounting. Forest Ecology and Management 264:228-37 (2012)

22. N. Oliveira, R.R. Soalleiro, C.P. Cruzado, I. Cañellas, H. Sixto, R. Ceulemans. Aboveand below-ground carbon accumulation and biomass allocation in poplar short rotation plantation under Mediterranean conditions. Forest Ecology and Management 428:57-65 (2018)

23. M. Yusuf, E. Sulistyawati, Y. Suhaya. Distribusi Biomassa di Atas dan Bawah Permukaan dari Surian (Toona Sinensis Roem.). Jurnal Matematika \& Sains 19(2):6975 (2014)

24. C.A. Siregar. Formulasi Persamaan Allometrik Untuk Pendugaan Biomassa Karbon Jati (Tectona grandis Linn. F) Di Jawa Barat. Jurnal Penelitian Sosial dan Ekonomi Kehutanan 9(3):160-9 (2012) 